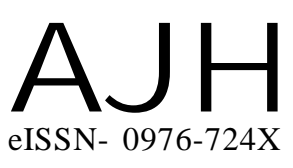

Article history : Received : 07.03.2018 Revised : 08.05.2018 Accepted : 22.05.2018

Members of the Research Forum Associated Authors:

${ }^{1}$ Department of Vegetable Science, C.S. Azad University of Agriculture and Technology, Kalyanpur, Kanpur (U.P.) India

\footnotetext{
Author for correspondence : Saurabh Dixit

Department of Vegetable Science, C.S. Azad University of Agriculture and Technology, Kalyanpur, Kanpur (U.P.) India

Email : sdixit307@gmail.com
}

THEASIAN JOURNALOF HORTICULTURE

Volume 13 | Issue 1 | June, 2018 | 18-21

Visit us -www researchjournal.co in

\section{Effect of different weed management strategies on weed dynamics and yield of Rabi onion (Allium cepa L.)}

\section{Saurabh Dixit, A.K. Dubey ${ }^{1}$ H.V. Dube ${ }^{1}$ and V.P. Singh ${ }^{1}$}

ABSTRACT : A field experiment was conducted to compare various weed management strategies in onion at Vegetable Research Farm, C.S.A. University of Agriculture and Technology, Kalyanpur, Kanpur during Rabi season in 2016- 2017. The experiment comprised of six treatments of pre-emergence and post-emergence of herbicides, their combination with hand weeding, mechanical or physical weed control and weedy check. The significant results revealed that pre-emergence application of oxyflurofen $23.5 \%$ EC before planting + one hand weeding at 4060 days after onion seedling transplanting recorded the higher marketable and total bulb yield ( 22.50 and $25.34 \mathrm{tha}^{-1}$, respectively) with maximum weed control efficiency of $87.02 \%$. The same treatment was also recorded higher cost benefit ratio of 1:2.86. However, this treatment was economically viable for control of weeds in case of labour scarcity with better bulb yield, weed control efficiency, benefit cost and keep the weed density lower level in Rabi season grown onion production under central U.P. conditions.

KEY WORDS : Weed, Growth, Yield, Onion

HOW TO CITE THIS ARTICLE : Dixit, Saurabh, Dubey, A.K, Dube, H.V. and Singh, V.P. (2018). Effect of different weed management strategies on weed dynamics and yield of Rabi onion (Allium cepa L.). Asian J. Hort., 13(1) : 18-21, DOI : 10.15740/HAS/TAJH/13.1/18-21. 